\title{
MEASUREMENTS OF DIURNAL VARIATIONS IN SNOW ALBEDO ON LEMON CREEK GLACIER, ALASKA*†
}

\author{
By Richard C. Hubley \\ (University of Washington, Seattle)
}

\begin{abstract}
Two Eppley pyrheliometers were used to measure incoming and reflected sun and sky radiation over a saturated, melting snowpack. Albedo values computed from these measurements varied strongly, not only with snow surface conditions, but also diurnally with the angle of the sun, and from clear to cloudy skies. On clear days minimum albedo in the afternoon was approximately 35 per cent less than the maximum in early morning; a secondary maximum occurred at sunset. Also, midday albedos were higher under cloudy skies than under clear skies. These variations appear to relate primarily to changes in angle of incident radiation, and secondarily to changes in the physical structure of the snow surface. Spectral changes in incident radiation are also a possible factor.

ZuSAMMENFASSUNG. Einfallende und reflektierte Sonnen- und Himmelsstrahlung wurde über einer gesättigten, schmelzenden Schneedecke mit Hilfe zweier Pyranometer (,Eppley pyrheliometers") gemessen. Hieraus ergaben sich Albedowerte, die erheblich nicht nur mit den Schneeoberflächenverhältnissen sondern auch mit dem Stand der Sonne im Tagesverlauf und zwischen klarem und bewölktem Himmel schwankten. An klaren Tagen wurde nachmittags ein Âlbedominimum gefunden, das ungefähr $35 \%$ unter dem frühmorgendlichen Maximum lag. Bei Sonnenuntergang zeigte sich ein sekundäres Maximum. Die Mittag-Albedos waten bei bewölktem Himmel

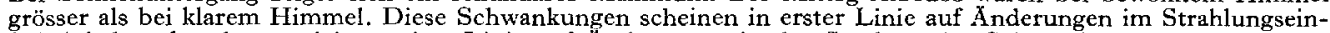
fallwinkel zu beruhen und in zweiter Linie auf Anderungen in der Struktur der Schneeaberfäche. Ausserdem besteht die Möglichkeit von Änderungen im Spektrum der einfallenden Strahlen.
\end{abstract}

DURING the summer of 1954, nearly continuous observations of incoming and reflected solar radiation over snow were conducted as an integral part of an investigation of the surface heat exchange on the Lemon Creek Glacier near Juneau, Alaska. Measurements were made with two Eppley ten-junction pyrheliometers, one upright and one inverted, mounted at a height of approximately $75 \mathrm{~cm}$. over a flat, nearly horizontal expanse of snow near the head of the glacier at $1200 \mathrm{~m}$. above sea level. Outputs of the pyrheliometers were measured by an automatic recording potentiometer which recorded a set of readings once every 24 seconds. A small $35^{\circ}$ watt gasoline motor generator was used as a power source for the potentiometer.

To determine heat exchange at the snow surface, the amount of solar radiation absorbed by the snow must be known, and in the present case is given directly by the difference between values measured by the two pyrheliometers. In earlier investigations of heat exchange at a glacier surface, continuous measurements have usually been made of the incoming solar radiation alone, and absorbed radiation ( $\left.I_{a}\right)$ calculated from the equation

$$
I_{a}=I_{o}(\mathrm{x}-\alpha)
$$

where $I_{0}$ is the insolation at the surface, and $\alpha$ the albedo of the surface. On the assumption that major variations in snow albedo occur only with variations in physical characteristics of the snow surface itself, albedos for use in the above equation have generally been determined from spot measurements made near the middle of the day over the snow surface under study. Basic in this earlier method, therefore, is the assumption that the albedo is independent of the sun's angle and of cloudiness.

In 1934, Olsson ${ }^{1}$ found snow albedos on Isachsen's Plateau to be different for clear than for cloudy skies; the difference being at a maximum, io per cent of the mean value. Albedo measurements published by Wallén ${ }^{2}$ show a trend for the albedo of wet older snow to increase with increasing cloudiness, although his measurements are too few to allow positive conclusions to be drawn as to the magnitude of the cloud effect. With reference to possible effects of the angle of the sun, Eckel and Thams ${ }^{3}$ found no dependence of albedo of the winter snow cover at Davos on solar altitude. In a later study, Prohaska and Thams 4 did find a tendency for the albedo of frozen, icy snow (Firnspiegel) to increase with decreasing solar altitude. Measurements at the Central Sierra Snow Laboratory, California, 5 during the 1948 spring melting period of the winter snowpack showed for May a slight diurnal variation of snow albedo amounting on the average

* Performed as part of the field program of the Juneau Ice Field Research Project, Alaska, directed by the American Geographical Society of New York under contract with the Office of Naval Research.

$t$ Contribution No. I 2, Department of Meteorology and Climatology, University of Washington. 
to 4 per cent of the daily mean. More recently, Sauberer and Dirmhirn 6 reported finding, on certain places near the summit of the Sonnblick, a regular diurnal variation of snow albedo during periods of good weather, which was noticeable to the naked eye. Quantitatively, Sauberer and Dirmhirn found that on days with midday temperatures several degrees above $0^{\circ} \mathrm{C}$., but with frost occurring at night, the albedo at many places varied regularly from early morning to afternoon, an amount equivalent to 34 to 50 per cent of the mean albedo. It is clearly evident at this point that the albedo properties of snow in general are not well established.

Albedos were calculated from this summer's solar radiation data to investigate further the validity of these earlier methods for determining solar radiation absorbed by the snow, and also to establish albedo characteristics of the type of snow present in the area under study.

During the period covered by measurements (late June to August) the snow was saturated with water, and continuously in a melting state with the exception of a few clear nights during which thin, icy crusts formed at the surface. Snow over which measurements were made had been extensively recrystallized and was composed of ice granules ranging from $\mathrm{I}$ to $2 \mathrm{~mm}$. in diameter on the average. Snow density measured near the surface averaged about $0.5 \mathrm{gm} . \mathrm{cm} .^{-3}$.

Mean albedos were computed for $7 \frac{1}{2}$-minute periods and plotted graphically against solar

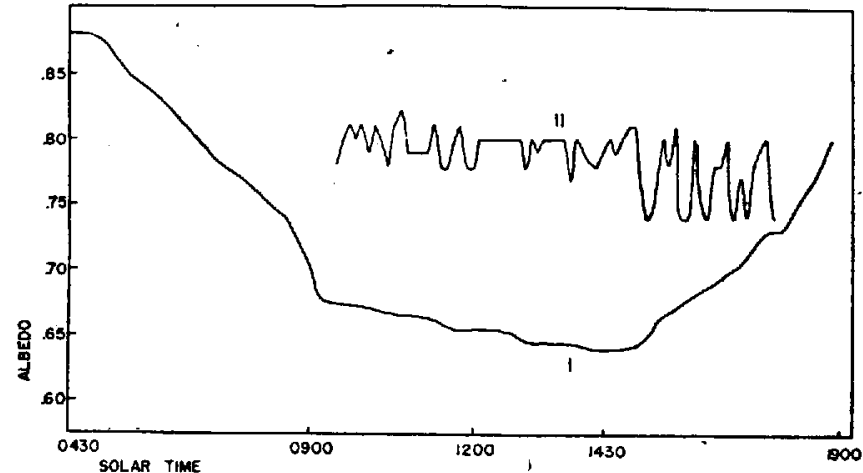

Fig. I (left). Curve I; snow albedo on a clear day Curve II; snow albedo with low overcast and fog

Fig. 2 (right). Variation of snow albedo with solar altitude under clear skies. The plotted values are averages, with vertical lines showing maximum deviation of individual values

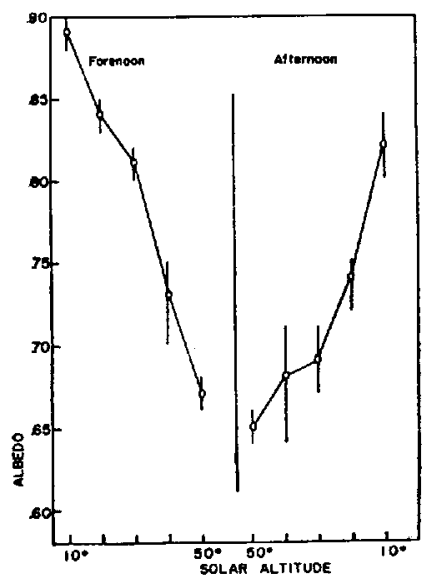

time. Results show that the albedo varied strongly both with angle of the sun and with cloudiness. Two extremes in diurnal variation patterns similar to those reported by Sauberer and Dirmhirn are shown in Fig. I (above). Curve $I$ in this figure demonstrates the change of albedo with time on a clear day, and Curve II, the variations on a completely overcast and foggy day. On the clear day shown, the snow surface had a frozen crust until approximately $09.00 \mathrm{hr}$., and remained in a wet, melting state throughout the rest of the day. On the cloudy day shown, the snow was wet and melting at all times. Variations in albedo were correlated with variations in density of fog lying over the station, being maximum when the fog was most dense. Average values of albedo at ten-degree intervals of solar altitude for four clear days on which observations were made are shown in Fig. 2 (above). In all cases, the snow surface was frozen during early morning hours when albedos were highest. Lower albedos in the afternoon as compared to those in the morning for any given angle are attributed to the effect of increased surface roughness through melting during the day. Vertical lines show the range of values observed for each solar altitude.

To summarize results of field measurements, the snow albedo was found to vary inversely with the height of the sun above the horizon, inversely as the height of any existing cloud layers, directly with thickness of overlying cloud layers when solar altitude exceeded some critical angle, and inversely with thickness of overlying cloud layers when the solar altitude was less than a 
critical angle. In short, the snow albedo varied directly with the percentage of incoming solar radiation received at low angles of incidence. On clear days the snow albedo averaged $3 \circ$ per cent higher near sunrise and sunset than during the midday. On days with complete overcast and no fog, midday albedos were approximately 15 per cent higher than midday values on a clear day. With an overcast and fog, midday albedos were as much as 30 per cent higher than midday albedos under clear conditions.

These observed variations in albedo can be accounted for by three principal effects: (I) Old, recrystallized snow and firn such as that found in summer on the Lemon Creek Glacier and other maritime glaciers produce a high degree of regular or specular reflection leading to a dependence of surface reflection on angle of incident radiation; (2) as has been verified by laboratory and field measurements, reflectivity of snow is a function of wave length of incident radiation; and (3) albedo is a function of physical characteristics of the snow, namely, grain size, grain structure, density, surface roughness, and free water content. In general all three factors are probably acting simultaneously to produce the observed albedo variations, presenting an exceedingly difficult problem in attempting to relate quantitatively the albedo variations to their causes.

Sauberer and Dirmhirn stress the importance of changes of free water content in the snow to variations in the albedo on clear days. Beyond doubt, this is a significant factor. In the present case, however, the albedo was found to fluctuate significantly and in phase with relatively rapid changes in the mean angle of incidence of incoming radiation as occurred, for example, during sunny periods when highly reflective cumuli clouds approached or receded from the observation site. This phenomenon is taken as indicative of the specular effect on albedo fluctuations. This dependence of albedo on angle of incident radiation may be the principal factor responsible for the over-all pattern of albedo variations observed on a clear day. Displacement of the time of minimum albedo from noon on clear days appears, on the other hand, to be associated with dependence of albedo on physical characteristics of the snow. Surface roughness of the snow was observed to increase during periods when melting was produced primarily by insolation, and to decrease when melting was produced primarily by wind. On sunny days observed this summer, time of minimum albedo was found to occur usually during a period of minimum windspeed during the day, consequently at a time of maximum surface roughness of the snow.

The presence of an overcast leads to a high degree of diffusivity of incoming short wave radiation, resulting in much less variation through the day of the mean angle of incidence as compared to a clear day, and, consequently, in attenuation of the diurnal albedo variation.

Instruments were not available this summer to investigate the effect of changes in spectra of incident radiation on the snow albedo, though it appeared to be considerably less significant than other effects.

Taking into consideration albedo characteristics found for other types of snow and described earlier in this paper, the pattern of albedo dependence on solar altitude seems to be as follows: new snow, particularly dry powder snow, is nearly ideal as a diffuse reflector, and has very little, if any, albedo dependence on angle of incident radiation. As snow metamorphism through melting and refreezing takes place, specular reflection appears, and so, consequently, does the variation of albedo with angle of incidence. Apparently this diurnal variation does not attain a large magnitude until recrystallization of the snow has progressed extensively. Maximum development of this diurnal albedo variation over glacier surfaces will probably be found over smooth, wet glacier ice where under clear conditions the albedo may vary from a value near one at very low solar altitudes to a value between 0.2 to 0.5 during the midday.

Further detailed investigations of glacier albedos from different areas are badly needed. Apart from their dependence on physical characteristics of the glacier surface, time of day, and cloudiness, glacier albedos must also be functions of latitude, elevation above sea level, season, and degree and direction of surface slope; all of these factors having influence on the angles and spectra of incident radiation.

MS. received 3 fanuary 1954 


\title{
R E F E R E N C E S
}

I. Olsson, Hilding. Radiation measurements on Isachsen's Plateau. Geografiska Annaler, Arg. 18, r936, p. $225-44$.

2. Wallén, Carl Christian. Glacial-meteorological investigations on the Kårsa Glacier in Swedish Lappland, I942-1948. Geografiska Annaler, Arg. 30, 1948, p. 45I-672.

3. Eckel, $O$., and Thams, Chr. Untersuchungen über Dichte-, Temperatur- und Strahlungsverhältnisse der Schneedecke in Davos. Der Schnee und seine Metamorphose, Beiträge zur Geologie der Schweiz-Geotechnische Serie; Hydrologie; Lief. 3, Zürich, 1939, p. 273-340.

4. Prohaska, F., and Thams, Chr. Neue Untersuchungen über die Strahlungseigenschaften der Schneedecke. Helvetica Physica Acta, Vol. I3, 1940, p. 21-44.

5. Cooperative Snow Investigations, Corps of Engineers Analysis Units. Albedo of the snow surface as related to weathering factors and stage of the season. Research Note, South Pacific Division, Corps of Engineers, U.S. Army, San Francisco, Calif., 1 I Dec., 1950 (mimeographed).

6. Sauberer, Franz, and Dirmhirn, Inge. Der Strahlungshaushalt horizontaler Gletscherflächen auf dem Hohen Sonnblick. Geografiska Annaler, A.rg. 34, Ht. 3-4, 1952, p. 261-90.

\section{GLACIOLOGICAL OBSERVATIONS ON SOME OF THE OUTLET GLACIERS OF SOUTH-WEST VATNAJÖKULL, ICELAND, I 954}

\author{
By Cuchlaine A. M. King and J. D. Ives \\ (University of Nottingham) \\ Part I: GLACIER REGIME
}

\begin{abstract}
Accumulation and ablation measurements on Morsárjökull are described and a tentative glacier budget for the three seasons $195 \mathrm{I}-52,1952-53$ and $1953-54$ is presented. Observations of glacier flow on Morsárjökull, Svfnafellsjökull and Skaftafellsjökull are considered. The recent fluctuations of the snouts of Skaftafellsjökull and Svinafellsjökull are discussed and related to variations in the height of the accumulation zones of the glaciers; recent glacier thinning is also mentioned.

Zusammenfassung. Anhäufungs- und Ablationsmessungen auf dem Morsárjökull werden beschrieben, und ein vorläufiges Gletscher-Budget für die drei Saisons $1955^{-52}$, I $95^{2-53}$ und $1953^{-54}$ ist aufgestellt.

Beobachtungen der Gletscherströmung auf dem Morsárjökull, dem Svínafellsjökull und dem Skaftafellsjökull werden in Betracht gezogen. Die jüngsten Schwankungen der Stromenden des Skaftafellsjökull und des Svínafellsjökull werden besprochen und auf Unterschiede in der Höhe der Anhäufungszonen der Gletscher bezogen; jüngster Gletscherschwund wird auch erwähnt.
\end{abstract}

\section{A. Accumulation}

The observations begun in 1953 on the south-west margin of Vatnajökull, in the accumulation area of Morsárjökull, were continued in the summer of 1954 . A pit, about $1 \frac{1}{2} \mathrm{~km}$. north of the Midfellstindur ridge, at $1200 \mathrm{~m}$. elevation was dug in the same area as the 1953 accumulation pit 2 to measure the firn accumulation during the winter of $1953^{-54}$ and to check the estimate for 1952-53 which was based on the measurements in the 1953 pit (see Fig. 1, p. 564). On 12 August 1954 the profile showed $3.65 \mathrm{~m}$. of firn overlying the 1953 summer horizon. The layer between the 1952 and 1953 summer surfaces was $1.33 \mathrm{~m}$., which is rather in excess of the estimate made on the 1953 measurements. It appears that ablation after 16 August 1953 only amounted to $0.4 \mathrm{~m}$. instead of the $0.9 \mathrm{r} \mathrm{m}$. estimated. This observation shows that the ablation period in 1953 must have ended sooner than is generally anticipated and earlier than suggested by Ahlmann's observations on south Vatnajökull between 1935 and I93 $8^{1}$. However, the observations do show that the amount of firn varies very much from year to year. The $1953^{-}-54$ season was particularly snowy; at the beginning of the ablation season the depth of snow at $1200 \mathrm{~m}$. must have been at least $5^{-6} \mathrm{~m}$.

\section{B. Ablation}

The ablation was measured in the accumulation zone of Morsárjökull in July and August I953. In I954 it was measured in the ablation zone of Morsárjökull and of Skaftafellsjökull and Svinafellsjökull, where the flow observations were made (see Fig. 4, p. 565). The ablation stakes on Morsárjökull were situated between the edge of the pro-glacial lake at $180 \mathrm{~m}$. and close to the back-wall at $560 \mathrm{~m}$. Another set of observations were made across the glacier where the flow was measured. The results are shown in Fig. 2 (p. 565). There appears to be little change in the rate of ablation down the glacier; possibly this is because the valley is narrow with steep rock walls. 